\title{
STUDI KOMPARATIF MOTIVASI BELAJAR BERDASARKAN TINGKAT PEREKONOMIAN KELUARGA SISWA KELAS VII SMP NEGERI 1 PANGARIBUAN, KECAMATAN PANGARIBUAN, KAB. TAPUT TAHUN PEMBELAJARAN 2017/2018
}

\author{
Ronny Simatupang \\ Institut Agama Kristen Negeri Tarutung \\ Email:ronnysimatupang75@gmail.com
}

\begin{abstract}
Abstrak - Penelitian ini bertujuan untuk mengetahui perbedaan motivasi belajar berdasarkan tingkat perekonomian keluarga siswa kelas VII SMP Negeri 1 Pangaribuan, Kecamatan Pangaribuan, Kab. Taput Tahun Pembelajaran 2017/2018. Hipotesa penelitian Terdapat perbedaan motivasi belajar yang signifikan berdasarkan tingkat perekonomian keluarga siswa kelas VII SMP Negeri 1 Pangaribuan, Kecamatan Pangaribuan, Kab. Taput Tahun Pembelajaran 2017/2018. Populasi penelitian adalah seluruh siswa kelas VII SMP Negeri 1 Pangaribuan, terkecuali siswa yang menerima bantuan operasional sekolah, berjumlah 156 orang (ekonomi mampu 89 orang dan ekonomi kurang mampu 67 orang). Sampel sebanyak 38 orang untuk kategori siswa keluarga mampu dan 30 orang untuk kategori siswa keluarga tidak mampu. Data dikumpulkan dengan angket tertutup sebanyak 30 item. Ujicoba diberikan kepada 30 siswa kelas VIII yang bukan responden penelitian. Dengan hasil uji validitas intrumen sebanyak 30 item dengan $r_{\text {hitung }}>r_{\text {tabel }}(0,05.30)$ yaitu $0,715>0,361$. Hasil uji reliabilitas instrumen diperoleh $\mathrm{r}_{11}=0,924$ berada pada interpretasi sangat tinggi, Dengan demikian dapat disimpulkan hipotesa penelitian diterima yaitu Terdapat perbedaan motivasi belajar yang signifikan berdasarkan tingkat perekonomian keluarga siswa kelas VII SMP Negeri 1 Pangaribuan, Kecamatan Pangaribuan, Kab. Taput Tahun Pembelajaran 2017/2018. Perbedaan motivasi belajar siswa diketahui dari Pencapaian tingkat motivasi belajar dari siswa yang berasal dari keluarga ekonomi mampu mencapai $81,80 \%$. Sedangkan pencapaian motivasi belajar siswa yang berasal dari keluarga ekonomi kurang mampu adalah 73,61\%.
\end{abstract}

Kata Kunci: Motivasi Belajar, Tingkat Perekonomian keluarga.

Abstract : This study aimed to determine the difference of learning motivation based on the level of grade 7 students' economy, at SMP 1 Pangaribuan, subdistrict of Pangaribuan, North Sumatra province. There were 68 students as the samples consisting of 38 students from economically well-off families and 30 students from economically destitute families. A questionaire was used to collect data from those participants. After conducting analysis, firstly, it was found that $r_{\text {count }}>r_{\text {table }(0,05.30)}$, which was $0.715>0.361$. Meanwhile, the reliability of instrument were obtained $r_{11}=0.924$ at a very high interpretation. Secondly, it can be concluded that the research hypothesis was accepted due to a significant difference in learning motivation based on the level of students' social economy was discovered. The difference for learning motivation from students' achievement of economically welloff families reached at $81.80 \%$. Whereas, learning motivation for students' achievement of economically destitute families reached $73.61 \%$.

Keywords: learning motivation; well-off families; destitute families; junior high school

\section{PENDAHULUAN}

Pendidikan adalah wahana yang dilalui peserta didik untuk mengembangkan potensi diri dalam suatu proses pendidikan yang sesuai dengan tujuan pendidikan. Tujuan pendidikan yang hendak dicapai pemerintah Indonesia adalah mencerdaskan kehidupan bangsa dan mensejahterahkan rakyat. Oleh karena itu pemerintah telah mengadakan perluasan kesempatan memperoleh pendidikan bagi seluruh rakyat
Indonesia. Hal ini sesuai dengan bunyi pasal 31 ayat 2 UUD 1945, yang mengatakan bahwa Setiap warga negara berhak mendapatkan pendidikan.

Fasilitas dalam dunia pendidikan sangatlah diperlukan untuk memperlancar proses pembelajaran. Jika fasilitas belajar kurang maka proses belajar akan terganggu, sebaliknya jika fasilitas belajar terpenuhi maka kelancaran dalam belajar juga akan terlaksana. Untuk itu diperlukan cukup uang 
untuk membeli fasilitas tersebut. Disini Keluarga bertanggung jawab menyediakan dana untuk memenuhi kebutuhan pendidikan anak-anaknya. Hal ini menandakan bahwa ekonomi keluarga merupakan pendorong terjadinya kelancaran pendidikan anak. Slameto (2013:63) mengatakan bahwa Keadaan ekonomi keluarga erat hubungannya dengan belajar anak. Anak yang sedang belajar selain harus terpenuhi kebutuhan pokoknya, misal makan, pakaian, perlindungan kesehatan dan lainlain, juga membutuhkan fasilitas belajar seperti ruang belajar, meja, kursi, penerangan, alat tulis-menulis, buku-buku dan lain-lain. Fasilitas belajar itu dapat terpenuhi jika keluarga mempunyai cukup uang. Keluarga mempunyai pengaruh yang besar terhadap proses belajar anak, karena keluarga adalah lembaga sosial pertama dalam kehidupan manusia. Didalam keluarga, orangtua memiliki tugas dan tanggung jawab yang sangat penting terutama dalam memenuhi kebutuhan anak baik itu kebutuhan pendidikan dan kebutuhan sehari-hari yang mencakup kebutuhan dari segi materil.

Pada realitanya dalam kehidupan masyarakat, orangtua memiliki status sosial yuang berbeda-beda. Orangtua atau keluarga yang tingkat ekonominya tinggi tidak mengalami kesulitan dalam memenuhi kebutuhan pendidikan anaknya karena memiliki banyak uang untuk memenuhi fasilitas anak dalam belajar. Berbanding terbalik dengan keluarga yang tingkat ekonomi rendah atau tidak mampu, akan mengalami kesulitan untuk memenuhi kebutuhan pendidikan anaknya, keadaan inilah yang mengakibatkan anak sulit untuk belajar, kesulitan dalam belajar akan mangacu pada menurunnya motivasi anak dalam belajar. Dengan alat yang serba tidak lengkap inilah maka hati anak-anak menjadi kecewa, mundur, putus asa sehingga dorongan belajar kurang sekali.

Berdasarkan pengamatan penulis semangat belajar siswa yang berasal dari keluarga kurang mampu masih rendah dibandingkan dengan siswa dari keluarga mampu. Perbedaan motivasi ini terlihat dari adanya siswa yang mengantuk dan tidak konsentrasi saat proses belajar mengajar, tidak mengerjakan tugas, telat mengumpulkan tugas, absen karena sepatu, tas dan pakaian yang sudah rusak, tidak memiliki berbagai perlengakapan penunjang pembelajaran, bahkan malas belajar dan tidak mau mencari sumber sumber dari media lain untuk memecahkan suatu masalah soal-soal. Kemungkinan besar hal ini disebabkan oleh kondisi ekonomi keluarga siswa yang berbeda tersebut.

Berdasarkan data yang diperoleh penulis, menunjukkan bahwa kebanyakan orangtua siswa memiliki penghasilan ratarata Rp. 500.000 - 1.400.000/bulan dan sebagian lagi berpenghasilan diatas Rp.1.500.000. Menurut Dinas Sosial, Tenaga Kerja dan Transmigrasi Kabupaten Tapanuli utara. Adapun tingkat pendapatan keluarga dibagi menjadi 2 tingkatan, yaitu 1) Tingkat Pendapatan Rendah : Kurang dari Rp. 1.500.000,-/bulan, 2) Tingkat Pendapatan Tinggi : Lebih dari Rp.1.500.000,-/bulan. Sementara, Sardiman (2013:75) mengatakan bahwa Motivasi belajar adalah faktor psikis yang bersifat non-intelektual yang berperan dalam hal penumbuhan gairah, merasa senang dan semnagat untuk belajar. Selanjutnya, Dimyanti dan Mudjiono (2013:87) mengatakan bahwa Motivasi dibedakan atas dua jenis, yaitu 1) Motivasi primer adalah motivasi yang didasarkan pada motif-motif dasar tersebut umumnya berasal dari segi biologis atau jasmani manausia. 2) Motivasi sekunder adalah motivasi yang dipelajari, yakni keinginan memperoleh pengalaman baru, untuk mendapat respon, memperoleh pengakuan dan rasa aman. Menurut, Slameto (2013:54-69) faktor yang mempengaruhi motivasi belajar ada dua, faktor intern dan ekstern yaitu 1) Faktor intern terdiri dari a) Faktor jasmaniah seperti kesehatan dan cacat tubuh, Proses belajar seseorang akan terganggu jika kesehatan terganggu dan mengalami cacat tubuh, selain itu juga ia akan cepat lelah, mudah pusing sehingga dorongan atau semangat untuk belajar jadi berkurang. Agar anak dapat belajar dengan baik haruslah mengusahakan kesehatan badannya tetap terjamin. b) Faktor psikologis seperti intelegensi, bakat, minat, Intelegensi besar pengaruhnya terhadap motivasi belajr. Dalam situasi yang sama, siswa yang mempunyai tingkat intelegensi yang tinggi akan lebih termotivai dalam belajar daripada yang mempunyai tingkat intelegensi rendah. Bakat juga dan minat 
juga turut mempengaruhi motivasi belajar. Jika siswa belajar sesuai dengan bakat dan hal yang diminatinyamaka hasil belajarnya akan lebih baik karena ia senang dan pastilah senjutnya ia lebih giat lagi belajar. 2 Faktor ekstern terdiri dari a) Faktor keluarga, seperti; cara orangtua mendidik, relasi anggota keluarga, suasana rumah, keadaan ekonomi keluarga, serta pengertian dari orangtua, siswa yang belajar akan menerima pengaruh dari keluarga. Orangtua yang kurang atau tidak memperhatikan pendidikan anaknya, misalnya mereka acuh tak acuh terhadap belajar anaknya, tidak memperhatikan kebutuhan-kebutuhan anaknya, tidak mengatur waktu belajarnya, tidak menyediakan/melengkapi alat belajarnya dan tidak membangun hubungan dalam keluarga yang baik dapat menyebabkan kemalasan dalam diri anak yang menurunkan motivasi mereka dalam belajar. b) Faktor sekolah meliputi; metode mengajar, relasi guru dengan siswa, disiplin sekolah, keadaan gedung, dll. Metode mengajar juga mempengaruhi semangat belajar. Metode mengajar yang kurang baik akan menghasilkan pembelajaran yang kurang baik pula sebaliknya jika guru menggunkan metode mengajar yang baik maka anak akan lebih memusatkan perhatiannya dalam belajar. Proses belajar mengajar tentu terjadi antara guru dengan siswa sehingga perlu interaksi yang baik diantara keduanya. Guru yang kurang berinteraksi dengan siswa akan menyebabkan proses belajar tidak lancar, selain itu siswa merasa jauh dari guru sehingga segan berpartisipasi secara aktif dalam belajar. Kedisiplinan juga mempengaruhi motivasi belajar sebab kedisiplinan membantu anak untuk semakin rajin datang kesekolahjuga dalam belajar.

Selanjutnya, Dimyanti dan Mudjiono (2013:97-100) mengemukakan bahwa, faktor-faktor yang mempengaruhi motivasi belajar ialah 1) Cita-cita atau aspirasi, motivasi belajar tampak pada keinginan siswa sejak dini seperti keinginan belajar, dapat membaca, dapat menyanyi dan lainlain. Keberhasilan mencapai keinginan tersebut menumbuhkan kemauan bergiat, bahwa dikemudian hari dapat menimbulkan cita-cita oleh perkembangan akal, moral, bahasa dan nilai-nilai kehidupan. 2) Kemampuan siswa, dalam belajar bagi siswa keberhasilan mengidentifikasi dan menganalisis serta meningkatkan motivasi dalam suatu pembahasan pembelajaran. 3) Kondisi siswa, kondisi siswa meliputi kondisi dari dalam dan dan luar siswa dari dalam yaitu kondisi jasmani dan rohani, seorang siswa yang sakit akan sulit memusatkan perhatiannya dalam belajar, dan jika siswa memiliki kondisi yang sehat maka akan memberikan perhatiannya dalam belajar dan kondisi rohani yang baik juga akan menambah motivasinya dalam belajar. Selain itu kondisi luar dari siswa juga mempengaruhi motivasi belajarnya yakni kondisi ekonomi orangtua dalam memenuhi kebutuhan belajar anak, menyediakan sarana prasarana belajar siswa. Siswa yang memiliki fasilitas belajar lengkap memiliki motivasi belajar yang kuat dan jika fasilitas belajar kurang maka keinginan anak untuk belajar akan berkurang. 4) Kondisi lingkungan, lingkungan kondisi yang sehat, kerukunan hidup, ketertiban pergaulan perlu dipertinggi mutunya, agar semangat siswa dalam belajar semakain bertambah. 5) Unsur-unsur dinamis dalam belajar dan pembelajaran, siswa yang memiliki perasaan, perhatian, ingatan, dan pikiran yang mengalami perubahan berkat pengalaman hidup. Pengalaman dengan teman sebayanya berpengaruh pada motivasi dan perilaku belajar. 6) Upaya dalam membelajarkan siswa, upaya guru dalam membelajarkan siswa untuk mencapai pengetahuan dan keterampilan sangat diperlukan guna menumbuh kembangkan semanagat belajar siswa.

Selanjutnya, Uno (2010:23) ciri-ciri motivasi belajar dapat diklasifikasikan sebagai berikut 1) Adanya hasrat dan keinginan berhasil. 2) Adanya dorongan dan kebutuhan dalam belajar. 3) Adanya harapan dan cita-cita masa depan. 4) Adanya penghargaan dalam belajar. 5) Adanya kegiatan yang menarik dalam belajar. 6) Adanya lingkungan belajar yang kondusif, sehingga memungkinkan siswa dapat belajar dengan baik. Asrori 2011 :184-185 mengatakan bahwaIndikator untuk mengetahui siswa yang memiliki motivasi dalam pembelajaran, diantaranya adalah 1) Memiliki gairah yang tinggi. 2) Penuh semangat hasrat untuk belajar. 3) Memiliki rasa penasaran atau rasa ingin tahu yang tinggi. 4) Mampu jalan sendiri ketika guru 
meminta siswa mengerjakan sesuatu. 5) Memiliki rasa percaya diri. 6) Memiliki daya konsentrasi yang lebih tinggi.7) Kesulitan dianggap sebagai tantangan yang harus di atasi. 8) Memiliki kesabaran dan daya juang yang tinggi. Sementara itu, menurut Linton dalam jurnal Ifdianto (2013:6) menyatakan bahwa dilihat dari segi ekonomi dalam masyarakat terdapat 2 (dua) lapisan masyarakat yaitu 1) lapisan ekonomi mampu/kaya ini mempunyai pendapatan tinggi, sehingga mereka dapat hidup layak. Contoh pekerjaan yang tergolong dalam ekonomi mampu/kaya adalah pejabat pemerintah setempat, pegawai swasta, insiyur dan kelompok profesional lain. 2) lapisan ekonomi miskin, lapisan masyarakat yang tergolong lapisan ekonomi miskin ini memiliki pendapatan yang minim.

Menurut Dinas Sosial, Tenaga Kerja dan Transmigrasi Kabupaten Tapanuli utara. Indikasi tingkat ekonomi keluarga berdasarkan penghasilan atau pendapat, dibagi atas dua, yaitu 1) Tingkat Pendapatan Rendah : Kurang dari Rp. 1.500.000,-/bulan. 2) Tingkat Pendapatan Tinggi : Lebih dari Rp.1.500.000,-/bulan. Selanjutnya, berdasarkan kriteria keluarga kurang mampu penerima Bantuan Langsung Tunai (BLT) poin ke 11 menyebutkan bahwa salah satu indikator ekonomi keluarga kurang mampu ialah:Sumber penghasilan kepala rumah tangga adalah: petani dengan luas lahan 0,5 ha,tani, nelayan, buruh bangunan, buruh perkebunan, atau pekerjaan lainnya dengan pendapatan di bawah Rp. 600.000 per bulan. http://studyofhealth23.blogspot.co.id/2018/0 8/konsep-dasar-status-ekonomi.html.

Beberapa pendapat tentang indikator tingkat pengahasilan golongan keluarga mampu dan tidak mampu, yaitu 1) Tingkat penghasilan menurut Saraswati (2009) a) Golongan atas (> Rp. 2.000.000/bulan). a) Golongan bawah (Rp. 1.000.000- 1.900.000/bulan). b) Tingkatan penghasilan menurut Badan Pusat Statistik tahun 2012, a) Golongan atas (Rp. 2.500.000-3.500.000/bulan). b) Golongan menengah (Rp. 1.500.00-2.500.000/bulan). c) Golongan bawah (<Rp. 1.500.000/bulan).

Sementara itu, ada beberapa indikator yang lebih luas lagi dalam menentukan kondisi ekonomi sosial keluarga mampu atau tidak mampu, yang dikemukakan oleh Badan Pusat Statistik (2015:84-91) mengatakan bahwa indikator kondisi sosial ekonomi keluarga ialah 1) Kualitas Rumah Tinggal/Kepemilikan Rumah, Status rumah tetap dan terjamin adalah rumah dengan status milik sendiri, sewa atau kontrak. Indikator ini bermanfaat untuk memperoleh gambaran tentang kemampuan penduduk atau rumah tangga untuk memenuhi salah satu kebutuhan dasar manusia yaitu tersedianya rumah yang layak huni. 2) Jenis atap, Jenis atap rumah juga mempengaruhi kualitas rumah, fungsi atap adalah untuk memberikan perlindungan kepada penghuninya, terutama dari panas dan hujan, oleh karena itu faktor jenis bahan yang digunakan turut memberikan pengaruh kepada kenyamanan penghuninya. Secara nilai ekonomi, jenis atap seng relative lebih murah dibandingkan genteng atau beton, namun pemilihan seng/asbes sebagai atap oleh rumahtangga di Tapanuli Utara memang tidak hanya dipengaruhi oleh tingkat pendapatan. 3) Luas lantai rumah, Luas lantai rumah suatu rumahtangga sangat berpengaruh terhadap kenyamanan dan kenikmatan bagi penghuninya. Idealnya rata-rata luas lantai per kapita minimal 10 $\mathrm{m}^{2}$. Jika dalam satu rumahtangga terdapat 45 anggota rumahtangga, maka idealnya rumahtangga menempati luas lantai minimal $50 \mathrm{~m}^{2}$. 4) Fasilitas rumah tinggal, Fasilitas rumah tinggal meliputi ketersediaan air bersih untuk minum, ketersediaan fasilitas buang air besar, listrik untuk penerangan dan jenis bahan bakar untuk memasak serta fasilita atau perabot rumah tangga lainnya.

Tuhan tidak melarang manusia untuk kaya dan tidak menginginkan hambanya untuk menjadi melarat, sebab itu manusia dituntut untuk bekerja untuk mendapatkan uang serta mampu memenuhi segala kebutuhan hidupnya, seperti yang tertulis dalam II Tesalonika 3:10c"...Jika seorang tidak mau bekerja janganlah ia makan". Artinya untuk dapat memenuhi segala kebutuhan hidup dan mencapai taraf hidup yang lebih baik (kaya) manusia harus rajin bekerja. Sebab orang yang rajin bekerja akan diberkati dan sebaliknya kemalasan membuat orang jatuh miskin Amsal 10:4 "Tangan yang lamban membuat miskin, tetapi tangan orang rajin menjadikan kaya.'Samuel (2010:36) mengatakan bahwa: kelas perekonomian manusia ada dua bagian, yaitu kaya dan miskin lalu 
dipecahkan menjadi empat bagian yaitu 1) Orang kaya dan tidak beriman (Lukas 11:3944). 2) Orang miskin dan tak beriman (1 Timotius 6:9). 3). Orang kaya dan beriman (Ulangan 6:10-12) dan, 4) orang miskin beriman (Lukas 18:35-42).

Doriza (2015:146) mengatakan bahwa ekonomi keluarga juga mempengaruhi motivasi belajar siswa, anak yang sedrang belajar membutuhkan fasilitas belajar yang lengkap selain kebutuhan pokok. Semua ittu didapatkan jika keluarga memiliki uang. Maka keluarga sebagai jembatan untuk menyiasati dinamika pendapatan dan pengeluaran keluarga. Natawidjaja (1979:77) mengatakan Anak-anak dari sosio-ekonomi lemah pada akhir pertama, memiliki dorongan belajar yangkurang daripada dorongan belajari anak-anak yang berasal dari sosio-ekonominya mencukupi. Anak-anak dari status ekonomi cukup memiliki semangat belajar yang lebih diakibatkan oleh sarana penunjang yang memadai yang dipenuhi oleh orangtua. Selanjutnya Bahar dalam jurnal Hendrawan (2015:49) mengemukakan bahwa anak yang berasal dari keluarga yang status sosial ekonominya rendah cenderung mempunyai motivasi yang rendah terhadap pendidikan. Dan sebaliknya anak yang berasal dari latar belakang sosial ekonomi yang tinggi, cenderung mempunyai motivasi yang tinggi terhadap pendidikan.

\section{METODE}

Penelitian ini merupakan penelitian komparatif deskriptif. Lokasi penelitian dilakukan di SMP Negeri 1 Pangaribuan. Adapun alasan penulis memilih lokasi tersebut adalah karena penulis melihat adanya masalah yang perlu diteliti mengenai motivasi belajar berdasarkan tingkat Perekonomian keluarga siswa. Yang menjadi populasi dalam penelitian adalah siswa kelas VII SMP Negeri 1 Pangaribuan Tahun Pembelajaran2017/2018 terkecuali siswa yang menerima bantuan operasional sekolah. Sampel dalam penelitian ini yakni $40 \%$ dari jumlah populasi yaitu 156 orang dengan kategori keluarga mampu 89 orang dan kategori keluarga tidak mampu 67 orang. Jadi sampel yang digunakan penulis sebanyak 38 orang untuk kategori siswa keluarga mampu dan 30 orang untuk kategori siswa keluarga tidak mampu. Uji coba instrumen ini dilakukan kepada siswa kategori keluarga mampu dan tidak mampu sejumlah 30 orang responden diluar responden yang telah ditetapkan, yakni siswa kelas VII SMP Negeri 1 Pangaribuan.

\section{HASIL}

Perolehan skor tertinggi untuk motivasi belajar siswa dari keluarga ekonomi mampu adalah item nomor 9 dengan skor 137 dan nilai rata-rata 3,60 yaitu siswa selalu belajar lebih giat lagi untuk mendapat prestasi yang lebih baik. Item nomor 3 dan 8 dengan skor 135 dan nilai rata-rata 3,55 yaitu siswa selalu mengerjakan tugas dengan bantuan bukubuku yang tersedia serta datang kesekolah tepat waktu. Sementara perolehan skor terendah adalah item nomor 20 dengan skor 92 dan nilai rata-rata 2,50 yaitu terdapat 11 orang siswa yang menjawab tidak pernah menyumbangkan saran atau ide-ide yang kreatif saat belajar. Dan item nomor 7 dengan skor 96 dan nilai rata-rata 2,52 yaitu 5 siswa menyatakan tidak pernah dan selebihnya hanya terkadang meluangkan waktu untuk belajar dengan teman-teman untuk memecahkan soal-soal yang sulit.

Perolehan skor tertinggi untuk motivasi belajar siswa dari keluarga ekonomi kurang mampu adalah 26 dengan skor 107 dan nilai rata-rata 3,56 yaitu siswa selalu berusaha berjuang memahami apa yang diajarkan oleh guru sampai benarbenar mengerti dan dapat menyelesaikan soal nantinya. Tertinggi selanjutnya adalah item 23 dengan skor 98 dan nilai rata-rata 3,26 yaitu siswa mampu mempertahankan pendapat yang diberikannya. Sementara itu pencapaian skor terendah dari item yang lainnya adalah nomor 30 dengan skor 73 dan nilai rata-rata 2,43 yaitu siswa jarang bahkan tidak pernah membeli buku pelajaran selain buku paket yang diberikan sekolah guna menambah wawasan dan pengetahuan mereka dalam menyelesaikan soal-soal. Terendah berikutnya adalah item nomor 18 dengan skor 80 dan nilai rata-rata 2,66 yaitu siswa jarang dan juga tidak pernah tertarik dengan pembelajaran yang membahas topik/materi yang baru.

Sesuai dengan hasil penelitian yang telah dianalisa dari hasil pengolahan data maka dapat diketahui pencapaian bobot motivasi belajar dari siswa keluarga 
ekonomi mampu mencapai 3730. Jika dibandingkan dengan bobot maksimal yaitu $30 \times 38 \times 4=4560$, artinya $81,80 \%$ dari keseluruhan indikator motivasi belajar telah dimiliki oleh siswa dari keluarga ekonomi mampu di kelas VII SMP Negeri 1 Pangaribuan.

Sedangkan motivasi belajar siswa dari keluarga ekonomi kurang mampu pencapaian bobot keseluruhan adalah 2653. Jika dibandingkan dengan bobot maksimal yaitu $30 \times 30 \times 4=3600$, artinya $73,61 \%$ saja dari keseluruhan indikator motivasi belajar yang dimiliki oleh siswa dari keluarga ekonomi kurang mampu di kelas VII SMP Negeri 1 Pangaribuan. Nilai ini lebih rendah dari pada motivasi belajar yang dimiliki siswa dari keluarga ekonomi Mampu.

Dari uji statistik yang bertujuan untuk mengetahui penerimaan atau penolakan hipotesa penelitian, diperoleh nilai $t_{\text {hitung }}$ lebih besar dari $\mathrm{t}_{\text {tabel }}$ yaitu $\mathrm{t}_{\text {hitung }}=13,351>\mathrm{t}_{\text {tabel }}=2,000$. Diketahui nilai $t_{\text {hitung berada pada }}$ daerah penolakan $\mathrm{H}_{0}$ dan penerimaan $\mathrm{H}_{\mathrm{a}}$. Dengan demikian dapat disimpulkan bahwa Terdapat perbedaan motivasi belajar yang signifikan berdasarkan tingkat perekonomian keluarga siswa kelas VII SMP Negeri 1 Pangaribuan. Tahun Pelajaran 2017/2018. Perbedaan dapat diketahui dari pencapaian bobot motivasi belajar siswa dari keluarga ekonomi mampu secara keseluruhan lebih tinggi daripada motivasi belajar siswa dari keluarga ekonomi kurang mampu.

\section{KESIMPULAN}

Berdasarkan hasil penelitian yang di temukan dalam penelitian ini maka di simpulkan bahwa, 1) Motivasi belajar siswa dari keluarga ekonomi mampu mencapai $81,80 \%$ dari keseluruhan indikator motivasi belajar. 2) Motivasi belajar siswa dari keluarga ekonomi mampu mencapai $73,61 \%$ dari keseluruhan indikator motivasi belajar.

3) Dari uji statistik dua pihak, diperoleh $t_{\text {hitung }}$ lebih besar dari $t_{\text {tabel }}$ yaitu $t_{\text {hitung }}=13,351$ $>t_{\text {tabel }}=2,000$. Diketahui nilai $t_{\text {hitung }}$ berada pada daerah penolakan $\mathrm{H}_{0}$ dan penerimaan $\mathrm{H}_{\mathrm{a}}$. Dengan demikian dapat disimpulkan bahwa terdapat perbedaan motivasi belajar yang signifikan berdasarkan tingkat perekonomian keluarga siswa kelas VII SMP Negeri 1 Pangaribuan Tahun Pelajaran 2017/2018. 4) Berdasarkan kesimpulan antara teoritis dan hasil penelitian yang telah diuraikan di atas maka dapat diambil kesimpulan akhir bahwa terdapat perbedaan motivasi belajar yang signifikan berdasarkan

tingkat perekonomian keluarga siswa kelas VII SMP Negeri 1 Pangaribuan dengan tingkat motivasi belajar dari siswa yang berasal dari keluarga ekonomi mampu mencapai $81,80 \%$ sedang motivasi belajar siswa yang berasal dari keluarga ekonomi kurang mampu hanya mencapai $73,61 \%$. Implikasi dalam penelitian ini adalah ekonomi keluarga merupakan pendorong terjadinya kelancaran pendidikan anak. Fasilitas belajar anak dapat terpenuhi jika keluarga mempunyai cukup uang, keluarga yang memiliki tingkat ekonomi tinggi memilliki motivasi belajar anak lebih tinggi karena mampu membutuhi fasilitas belajar anak. Sehingga siswa sangat tertarik dengan pembelajaran yang diajarkan oleh guru dan tetap berusaha berjuang memahami apa yang diajarkan oleh guru. 


\section{DAFTAR PUSTAKA}

Ahmadi, Abu. 2002. Psikologi Sosial. Jakarta: Rineka Cipta

Arikunto, Suharsimi. 2010. Prosedur Penelitian: Suatu Pendekatan Praktek. Jakarta: Rineka Cipta

Asrori, Muhammad. 2011. Psikologi Pembelajaran. Bandung: Wacana Prima

Badan Pusat Statistik. 2015. Indikator Kesejahteraan Rakyat Kabupaten Tapanuli Utara.

Dalyono, M. 2009. Psikologi

Pendidikan Jakarta: Rineka Cipta

Doriza. Shinta. 2015. Ekonomi Keluarga.

Bandung: Rosda Karya

Gunarsa, Ny. Singgih, D 1991.Psikologi perkembangan anak dan remaja. Jakarta: BPK Gunung Mulia 1988. Psikologi Untuk Keluarga. Jakarta: BPK Gunung Mulia

Hamalik, Oemar. 2009. Proses Belajar Mengajar. Jakarta: Bumi Aksara

Hasbullah. 2005. Dasar-dasar Ilmu Pendidikan. Jakarta: Raja Grafindo

Lembaga Alkitab Indonesia. 2012. Alkitab dengan Kidung Jemaat. Jakarta

Mudjiono dan Dimyanti. 2013. Belajar dan pembelajaran. Jakarta: Rineka Cipta

Natawidjaja, Rochman.1979. Psikologi Umum dan Sosial. Jakarta : Departemen Pendidikan dan Kebudayaan.

Samuel. 2010. Memuliakan Tuhan dengan Harta. Yogyakarta: Andi Sardiman A.M. 2013. Interaksi dan Motivasi Belajar Mengajar. Jakarta: Rajawali Pers Setio, Robert. 2002. Teologi Ekonomi. Jakarata: BPK Gunung Mulia Slameto. 2013. Belajar dan faktor- faktor yang mempengaruhi. Jakarta: Rineka Cipta

Soekanto, soerjono. 2004. Sosiologi Keluarga. Jakarta: Rineka Cipta.

Sugiyono. 2013. Metode Penelitian Kuantitatif Kualitatif dan $R$ dan $D$. Bandung: Alfabeta

Uno, Hamzah. B. 2010. Teori Motivasi dan pengukurannya: Analisis di Bidang Pendidikan. Jakarta: PT Bumi Aksara

User Usman. Moh. 2010. Menjadi guru profesional. Bandung: Remaja Rosdakarya

Zain, Badudu. 1996. Kamus Umum Bahasa Indonesia. Jakarta: Pustaka Sinar Harapan

Hendrawan. 2015. Perbedaan Motivasi Belajar Siswa Keluarga Menuju Sejahtera Dan Siswa Reguler Program Keahlian Teknik Bangunan Di Smk Negeri 3 Yogyakarta.

Ifdianto. 2013. Jurnal Penelitian Pengaruh Status Sosial Ekonomi Terhadap Motivasi Belajar siswa. Kelas VII SMP Negeri 1 Kabila Kab.Bonebolango

Nazir. 2005. Jurnal Penelitian Komparatif (Ex Post Facto Research)

Puspitawati, Herien. 2013. Ketahanan Dan Kesejahteraan Keluarga

Rejeki. Sri. 2011. Pengaruh Kondisi Ekonomi keluarga, Motivasi Belajar, dan Gaya Belajar TerhadapHasil Belajar Siswa.

Sunarti. Euis. 2006. Indikator Keluarga Sejahtera: Sejarah pengembangan, Evaluasi dan Keberlanjutannya.

Suparyanto. Ekonomi Keluarga. Http//www.com.ec. keluarga.id. http://studyofhealth23.blogspot.co. id/201 8/08/konsep-dasar-statusekonomi.html 